\title{
Hashtag, like or tweet: a qualitative study on the use of social media among dentists in London
}

\author{
Aditi Mondkar, ${ }^{\star 1}$ Sasha Scambler² and Jennifer E. Gallagher ${ }^{3}$
}

\section{Key points}

Social media can play an important role in communication between dentists. This study suggests that dentists are aware of the risks and benefits of using social media and employ some management techniques to balance them.
Analysis suggests a range of social media user types representing their views, use and how they use social media in learning.
Given that social media is constantly evolving, dentists should be equipped with the right understanding and skills to manage and use these platforms throughout their professional careers.

\begin{abstract}
Aim To explore dentists' perceptions and use of social media generally and in relation to their professional careers, together with its implications for professionalism.

Methods Semi-structured interviews were conducted with dentists in their early, mid-and late careers working in a range of settings based in London. Participants were purposively sampled via gatekeeper organisations, supported by snowball sampling. Interviews were audio-recorded, transcribed verbatim and data were analysed using thematic analysis.

Results Eighteen dentists working across a range of career stages and care settings were interviewed. Participants were aware of the risks and benefits of using social media and expressed ways of balancing them. A typology of social media user types in the dental profession emerged from the data, comprising avoiders, secondary users, occasional users, observers, seekers, active and cautious, limited, engaged users and deleters. Participants reported an awareness of the impact of maintaining professionalism when using social media.

Conclusion Among the participant population sampled, the risks and benefits of general and professional social media were discussed and, in some cases, these overlapped. The findings suggest that dentists are aware of the risks and benefits and employ techniques to balance risk. There were a range of social media user types that varied by characteristics, use in learning and the influences that change their use. It was evident that social media plays an important role in communication between those dentists engaging with available platforms. This area requires further research into professionalism and social media in dentistry.
\end{abstract}

\section{Introduction}

The internet has evolved dramatically since its introduction by Tim Berners-Lee in $1989 .{ }^{1}$ Today, the digital world is an integral part of our lives, including widespread use of social

'Speciality Registrar in Dental Public Health, Visiting Research Associate, King's College London, Faculty of Dentistry, Oral \& Craniofacial Sciences, 2nd Floor Dental Institute Extension, Bessemer Road, London, SE5 9RS,

UK: ${ }^{2}$ Reader in Medical Sociology, Faculty of Dentistry, Oral \& Craniofacial Sciences, Floor 18, Tower Wing, Guy's Campus, King's College London, London, SE1 9RT, UK; ${ }^{3}$ Dean for International Affairs, Newland-Pedley Professor of Oral Health Strategy, Honorary Consultant in Denta Public Health, Faculty of Dentistry, Oral \& Craniofacial Sciences, King's College London, 2nd Floor Dental Institute Extension, Bessemer Road, London, SE5 9RS, UK.

*Correspondence to: Aditi Mondkar

Email address: Aditi.Mondkar@kcl.ac.uk

Refereed Paper.

Accepted 23 June 2020

https://doi.org/10.1038/s41415-021-2655-2 media. Eighty-seven percent of the population uses the internet daily or almost daily and 79\% of adults are reportedly accessing the internet through mobile devices or smartphones, ${ }^{2}$ thus providing easy connectivity to social media.

There are multiple definitions of social media, with a lack of consistency between them. ${ }^{3,4}$ One of the most used definitions was suggested by Kaplan and Haenlein in 2010: 'a group of Internet-based applications that build on the ideological and technological foundations of Web 2.0, and that allow the creation and exchange of user-generated content'. ${ }^{5}$ They considered the following six areas to be social media: collaborative projects (Wikipedia), blogs, content community (YouTube), social networking sites (Facebook), virtual game worlds and virtual social worlds - e-mail and instant messaging were not considered. ${ }^{5}$ As technology has developed, what is considered as social media has also developed. ${ }^{3,6,7,8}$
Social media is an important tool that may be utilised in a personal and/or professional manner, impacting the way we communicate with one another, work and learn; with it comes strengths and weaknesses, presenting challenges to those who use it. ${ }^{6,9,10}$ The increased use of social media by the dental profession has been acknowledged. In 2016, the General Dental Council (GDC) updated the published Guidance on using social media. ${ }^{11}$ This recognition of social media by the regulatory body highlights the impact it has and will have on the dental profession, in terms of changing the ways in which dentists communicate and approach their learning needs. In the United Kingdom (UK), dentists are required to complete continuing professional development (CPD) as part of their registration. ${ }^{12,13}$ This is mainly through traditional methods of attending courses, journal clubs, conferences and speaking with colleagues. ${ }^{14}$ However, with digitalisation of 
society, social media has a role to play in online learning. ${ }^{15,16}$

As with social media, professionalism can also be defined in different ways. ${ }^{17}$ Online professionalism ('e-professionalism') has been defined by Neville and Waylen as 'behaviour related to professional standards and ethics when using electronic communications. ${ }^{18}$ Behaviour of professionals can differ offline and online, and there are challenges of 'e-professionalism' for the dental profession. ${ }^{19,20}$

Research exploring the use of social media is well established and is developing among medical and allied health professionals. ${ }^{21,22,23,24,25,26,27,28}$ In the dental profession, there has been some research on how social media is being used by dentists. ${ }^{29,30,31,32,33}$ The majority has focused on social media in relation to undergraduates or newly graduated dentists, focusing on professionalism and education. ${ }^{6,9,15,18,20,34,35}$ The impact of social media use among qualified dentists across different career stages and working environments is unclear. Given the paucity of the research in this area, an inductive approach allows us to explore experiences, understanding and use of social media among dental professionals.

\section{Aim and objectives}

The aim of this study was to explore dentists' perceptions and use of social media generally and in relation to their professional careers, together with its implications for professionalism.

The objectives were:

1. To explore participants' perceptions and use of social media in general and in relation to dentistry

2. To explore participants' understanding of professionalism and social media use.

\section{Methods}

GDC-registered dentists working in general practice, community dentistry or in hospital (as a trainee, specialist, consultant or academic) were invited to participate in this study. The sample consisted of dentists in early, middle and late career stages based in London who may or may not have used social media. Ethical approval from the King's College Research and Ethics Committee (Ref: HR-17/18-5086) was obtained.

This study used career stages to categorise participants rather than age to link social media use directly to participants' professional career. Data suggests that age is related to use of social networking sites ${ }^{36}$ and this may change as society begins to use technology more. The dentistry programme welcomes direct entry from school leavers and mature students; therefore, age does not necessarily correspond to the career stage of an individual. For this study, career stages were defined as the number of years post-qualification, as below:

- Early (qualified up to and including ten years)

- Middle (11-25 years post-qualification)

- Late (those who have worked 26 years or more).

Participants were recruited through gatekeepers based in London (for example, the British Dental Association and the Federation of Local Dental Committees). Participants were screened using the inclusion criteria and purposively sampled to secure adequate representation among the sample being studied. Sampling was supplemented by snowball sampling. ${ }^{37}$ Semi-structured interviews were carried out in two phases. The majority of the data were collected in 2018 (April to June) and supplementary interviews were conducted in 2019 (March to June) to ensure coverage of all the key categories.

Informed written consent was gained on the day of the interview. Interviews were recorded and transcribed verbatim by the lead researcher. The interview topic guide was informed by the literature and piloted on dentists fitting the selection criteria and amended accordingly. Topics included participants' current, historical and future use of social media, CPD and professionalism online.

An interpretive phenomenological approach was adopted during data collection and analysis, ${ }^{38,39}$ together with an initial framework to support the analysis. ${ }^{37,40}$ The lead researcher familiarised herself with the data having transcribed interviews verbatim. A precis for each participant was created and the initial framework, based on the literature and reading/re-reading the transcripts, was used to identify the themes and subthemes.

Consequently, data were indexed and sorted, allowing for abstraction and interpretation; from this, categories were developed and participants were classified into social media user types, from which a list of user types emerged and views of the participants were mapped. ${ }^{37}$ Analysis of data was completed by hand and managed with Microsoft Excel.

\section{Results}

A total of 18 dentists took part in this study; the demographic details of participants are presented in Table 1. At the time of data collection, many of the participants had varied careers in their respective fields. Five main themes emerged from the data during analysis: 1) perceptions and use of social media and platforms; 2) risks and benefits; 3) management of social media; 4) online professionalism; and 5) emergence of a list of user types. The themes are presented below and illustrated by quotations, which are labelled by the participants' career stage, gender and professional role.

Table 1 Participant demographics (total number of participants = 18) (GDP = general dental practitioner, CDS = community dental service)

\begin{tabular}{|c|c|c|c|c|}
\hline \multicolumn{2}{|c|}{ Participant demographics } & \multicolumn{2}{|c|}{ Gender } & \multirow{3}{*}{$\begin{array}{l}\text { Total gende } \\
9\end{array}$} \\
\hline & & \multirow{2}{*}{$\begin{array}{l}\text { Male } \\
6\end{array}$} & \multirow{2}{*}{$\begin{array}{l}\text { Female } \\
3\end{array}$} & \\
\hline & Primary & & & \\
\hline & Secondary & 4 & 5 & 9 \\
\hline \multirow{6}{*}{ Role } & GDP & 5 & 1 & 6 \\
\hline & CDS & 1 & 2 & 3 \\
\hline & Specialist & 1 & 2 & 3 \\
\hline & Trainee & 1 & 1 & 2 \\
\hline & Consultant & 1 & 2 & 3 \\
\hline & Academic & 1 & 0 & 1 \\
\hline \multirow{3}{*}{ Career stage } & Early & 3 & 3 & 6 \\
\hline & Middle & 4 & 2 & 6 \\
\hline & Late & 3 & 3 & 6 \\
\hline
\end{tabular}


Perceptions and use of social media and platforms

Dentists' narratives indicated that there was a lack of clarity regarding the definition of social media, each defining it in their own way. Most participant definitions were based on the idea of making connections, communicating and sharing views; these came along with acknowledging the risks of oversharing, addiction and exposing oneself. For example:

- '[...] any form of media where the content is contributed by your peers or other people online. Also, the quality assurance and the vetting is also done by other people online' P2 (early, male, general dental practitioner)

- '[...] technological mediums where people can share photos, videos, ideas, post to a wide audience and connect with people who they don't necessarily know' P7 (middle, female, specialist).

The main social media platforms used for personal and/or professional purposes varied and included Facebook, Twitter, Instagram, Google+, Reddit, YouTube, Snapchat, and blogs such as GDPUK and Dental Town. There were conflicting views as to whether messaging platforms, such as WhatsApp, are considered social media. It was also proposed that different platforms are used for different purposes by different generations, as suggested by the following:

- 'I would include things like Snapchat, but I think that it's a bit blurred in terms of different generations might use it differently. For example, I have cousins who use Snapchat in a way they just message each other on it, whereas I would use WhatsApp for that. I wouldn't call WhatsApp a social media, I'd call that a messaging app' P3 (early, female, community dental service).

All participants acknowledged that social media is intertwined in our daily lives and becoming more relevant. Participants reported devices used to access social media, which included smartphones, tablets, laptops and computers. Their use of social media was related to their career stage.

Almost all the early and middle career participants started using social media before or during university. The late career participants did not use social media or used it minimally. The majority noted that they initially used it personally; this has changed over the years and is now used either personally, professionally or a mix. Additionally, the reported activity and type of platforms used varied, depending on the reason for which it is being used. These are both illustrated below:

- '[...] it's definitely evolved from what was initially for socialising to I guess a way of marketing, advertising, networking, connecting with other professionals' P15 (early, female, specialist)

- '[...] mix between social, professional, to kind of, it kind [sic] overlaps in certain bits of social media. So, Facebook I try and keep mostly personal. I do have a (professional) Facebook page [...] Twitter I usually [use], that's more professional, in a way for a way for me to promote my views' $\mathrm{P} 3$ (early, female, community dental service).

\section{Risks and benefits}

A range of risks and benefits were perceived by participants when using social media; these have been identified as being personal or professional and have been placed into themes. The full list which was identified can be seen in Table 2 .

\section{Risks}

Participants reported perceived personal risks of social media, which required an element of control, as addictive and time consuming; targeted advertising was perceived in some cases as an invasion of privacy, with platform algorithms creating an 'online bubble' of being exposed to top interactions:

- 'A challenge can be, however, a lot of people who are more impressionable can be targeted [...] you can get an advert going around, this or you'll get struck [...] a lot of people try to target that fear people have and I think that's one of the biggest, it's, that's one of the dangers, the dangers of falling for prey for the misuse' P2 (early, male, general dental practitioner).

Risks of poor communication were also identified, such as lack of engagement and presence during face-to-face conversations, risks of conversations being misinterpreted over online written communication, or questioning the validity of the user's qualifications or source and quality of information. Feelings of lack of confidentiality and trust were reported:

- 'Confidentiality, credibility of the information, things like that, those are the challenges I'd say' P9 (early, male,general dental practitioner).

The volume of information on social media was a risk and was suggested to be overwhelming, which users can scroll past or be misled by with 'fake news'. Security was acknowledged and, even though there was safety of closed threads, there was indication for concerns of hacking or false members:

- '[...] there's the potential to mislead, people can't verify who you are [...] it's very difficult for you to ascertain who's who and what's what, and whose advise you can actually take on board. I guess that that's the difficulty of social media, you don't know if people have the qualifications to back up what they are saying' P6 (middle, male, specialist).

Some participants perceived social media as a way of creating legacy, with the method of 'self-promotion' in a professional context in closed groups. Posting cases that went well could be interpreted as showing off or creating competitiveness, in some cases leaving users with the feeling of inadequacy. Participants' experience of seeing cases that went well on social media were positive but they felt there was an opportunity to learn from things that did not go well. However, they recognised that this may be avoided due to 'digital footprints' and risks of litigation:

- '[...] where people are posting their clinical photos and posting their before and after pictures. It's kind of competitive, one-upmanship and it makes you more critical of yourself $\mathrm{P} 2$ (early, male, general dental practitioner).

\section{Benefits}

Perceived personal benefits by participants included the ability to connect with friends, likeminded individuals and professional colleagues. Access was convenient, fast and instant when using mobile devices connected to the internet to allow access to share knowledge for free. Social media was seen to support engagement in the community, the feeling of anonymity being beneficial for those who are reluctant in face-to-face engagement, particularly in closed groups where the feeling is more secure:

- 'I think it's much [...] easier to connect with likeminded individuals and I definitely have connected with other people through social media introductions' P3 (early, female, community dental service).

From a professional aspect, users felt social media provides a forum for networking with colleagues. Some participants found it supportive in learning and enabling discussions among colleagues, and directive towards online CPD; it creates a community and allows personal professional development to take place: 
- 'I think it's different [...] it attracts a certain type of person, like you see on those forums it's the same names posting, I'm not sure if the same individuals would give a seminar, give a talk, put their hand up in a room of 40 people and say oh right actually this is what I would do [...] I think it creates that platform for discussion and debates. It gives people opportunity and it allows other people to share their experience and knowledge' P6 (middle, male, specialist).

Participants described how seeing successful cases reported was inspiring and helped to create referral pathways to benefit patient care; it provides a virtual platform where knowledge, advice and support can be shared.

The participants perceived and reported to have recognised the risks and benefits of social media, in both personal and professional lights. They perceived this as a tool which, if used correctly, can be beneficial to support the workforce and personal professional development. The management of social media is summarised in Table 2.
From the data presented, participants perceived that social media can be used adequately with good management; this requires a balance. They exhibited behaviours to manage this tension by having balance of competing needs, with an element of self-protection by adjusting settings on the platform, as the below quotes explore:

- 'I don't know if it's [social media] good or bad, it just depends on how you use it' P7 (middle, female, specialist)

- '[...] it depends how involved into social media you get, it is always bad when you go too far to one extreme, but there's middle area which

\section{Table 2 Perceived risks and benefits of social media in the dental profession}

\begin{tabular}{|c|c|c|}
\hline $\begin{array}{l}\text { Type of } \\
\text { benefit/risk }\end{array}$ & Benefits & Risks \\
\hline Personal & $\begin{array}{l}\text { Communication: } \\
\text { Connecting with friends, likeminded individuals, professional } \\
\text { colleagues } \\
\text { Medium to share knowledge } \\
\text { Convenience: } \\
\text { Instant, easily accessible, fast, constantly connected, supported with } \\
\text { mobile devices connected to the internet } \\
\text { Cost is free }\end{array}$ & $\begin{array}{l}\text { Control: } \\
\text { Can become addictive and therefore time consuming } \\
\text { Communication: } \\
\text { Lack of engagement and presence when face-to-face due to social } \\
\text { media } \\
\text { Confidentiality } \\
\text { Conversations can be misconstrued or misinterpreted } \\
\text { Potential to mislead users with information, such as 'fake news' } \\
\text { Volume: } \\
\text { Too much information, risk of feeling overwhelmed or risk of } \\
\text { ignoring information } \\
\text { Legacy: } \\
\text { Digital footprint and loss of privacy, once it's online it's on forever } \\
\text { and do not know who can access this information }\end{array}$ \\
\hline Professional & $\begin{array}{l}\text { Communication: } \\
\text { Enables networking with professionals, like-minded individuals } \\
\text { Creates dental communities which reduces the feeling of isolation, } \\
\text { specifically for GDPs } \\
\text { Social media can provide confidence to those who are shy at engaging in } \\
\text { face-to-face learning activities } \\
\text { Trust: } \\
\text { Security of closed group allows conversation } \\
\text { Can create trusting relationships } \\
\text { Control: } \\
\text { Some platform algorithms create a feeling of being in a bubble, which } \\
\text { allows you to be more aware of what is happening among your network } \\
\text { Targeted professional advertising can be beneficial in some cases, where } \\
\text { tailor-made advertising suggested items or courses which may support } \\
\text { learning needs } \\
\text { Knowledge: } \\
\text { Supports learning, discussions among colleagues, sharing advice and } \\
\text { useful tips } \\
\text { Increases awareness of jobs, courses and career options in dentistry } \\
\text { Exposes user to suggestions of solutions of common problems and new } \\
\text { topics } \\
\text { Useful in aiding personal development and directing to online CPD (eg } \\
\text { mandatory training elements) } \\
\text { Provides insight into common challenges among the dental community }\end{array}$ & $\begin{array}{l}\text { Quality: } \\
\text { Poor quality of information, can lead to scepticism and risk of taking it } \\
\text { for face value } \\
\text { Lack of validity of user source of information and qualifications of users } \\
\text { Trust: } \\
\text { Of platform management and participants } \\
\text { Control: } \\
\text { Platform algorithms allow friends of friends in network to see user } \\
\text { interactions, meaning you may or may not know who else is seeing your } \\
\text { posts and comments. This creates a feeling of being in a 'bubble' which } \\
\text { means you only see what is coming up on your feed, risk of missing out } \\
\text { on information } \\
\text { Targeted professional advertising can feel like an invasion of privacy, } \\
\text { with it being lost } \\
\text { 'Keyboard warriors', feeling of anonymity online allows the feeling of } \\
\text { informal discussions and e-professionalism can be forgotten } \\
\text { Legacy: } \\
\text { Can be used for self-promotion, users can be seen as 'showing off' or } \\
\text { 'beefing up' } \\
\text { Users can appear arrogant or risk creating a negative reputation } \\
\text { Users tend to post things that went well, so only see the things that } \\
\text { went well } \\
\text { Leaving a digital footprint risks repercussions in the future } \\
\text { Knowledge: } \\
\text { Social media directing to online courses, cannot replace practical } \\
\text { learning in dentistry }\end{array}$ \\
\hline Management & \multicolumn{2}{|c|}{$\begin{array}{l}\text { Adjusting settings on platform (privacy settings and changing profile name to reduce chance of patients connecting) } \\
\text { Time keeping (setting times of the day to use social media) } \\
\text { Maintaining social etiquette (keep phones away from table to engage in conversation) } \\
\text { Keeping a professional and personal account } \\
\text { Filtering information using own judgement on content, taking into consideration the qualifications and background of person providing answers/ } \\
\text { information, number of comments and context to situation, not taking it for face value, this can then steer you in the right direction if used appropriately } \\
\text { Not having applications on phones, using certain platforms on different devices }\end{array}$} \\
\hline
\end{tabular}


is beneficial' P9 (early, male, general dental practitioner)

- 'I haven't put my full name on it because I didn't want patients to contact me on it' P11 (middle, male, community dental service).

Participants filtered information through their own judgement and skills, such as critically appraising information as they would do for a scientific journal. Others filtered information utilising the platforms' methods of verifying high-profile and influential users:

- 'I use my own critical appraisal skills, you know, just like I would anyways, if I pick up a journal and I read something. I don't always sort of sit there and think that that person wrote this article and that's exactly what I am going to do. You know, I read and I look at what the basis of the argument is, is there any evidence to support it, what's the quality of that evidence and you ask these questions in your mind' P17 (middle, male, consultant)

- 'I mean I guess that is a problem [unregulated information] but then there are ways to verify, like on Twitter you have your official verified tick, you know things on Facebook, you can make sure that you use the official page and you can report things on Facebook if they aren't correct, I think there are safety net [sic] in there to help you know stop things getting you know' P3 (early, female, community dental service).

A few participants, from different career stages, exhibited an element of control when managing social media; for example, by managing information which is posted and by policing their own vested interest to ensure no negative exposure. Self-awareness and reflexivity were key here, requiring the user to be aware of what they are posting, as everything has the potential to be shared more widely than originally intended and 'go viral':

- '[...] I am actively using is Facebook and Instagram, that's because on Instagram, one of our practices [...] has a [sic] Instagram account and they post things. So my role for that is to make sure that they post the right sort of stuff and to make sure it is in the guidelines that we have [...] again I look at the Facebook for the same reasons' P16 (late, male, general dental practitioner )

- '[...] well it's like a, just a quick and simple way of communicating [...] Same with social media, you put up a post, you got to say it once, and it's like bang, it's like a virus it's just spread. And everybody that is linked to your profile or whatever gets to know. And there's no other way to do that' P17 (middle, male, consultant).

\section{Online professionalism and social media}

Maintaining professionalism online, 'e-professionalism', was highlighted as an important aspect to using social media by all participants.

\section{Defining e-professionalism}

There was variation in participants' definition of e-professionalism; overall, it was viewed as common sense, making sure that online behaviour reflects that offline and maintaining social etiquette as you would in person and in group settings. The quotes below represent this understanding and reiterates the need for barriers to maintain professionalism:

- 'I think it's maintaining a barrier between your professional life and your personal life, not overstepping those boundaries and making sure you are still, you still appear professional too, because you will have patients trying to [access] or be able to see your online profiles' P3 (early, female, community dental service)

- 'I think what you do online has to conform to the same standards as whatever you do face to face' P7 (middle, female, specialist).

There were underlying themes of confidentiality, regulatory body and NHS information governance. All participants were aware of the nature of a digital footprint and the consequences that this may have in the future:

- '[...] a big aspect is that withe-professionalism, everything is going to be recorded and everything is going to be online for a long time, so something you post as a young dentist that you might not particularly like [...] that's all going to be recorded on social media' P9 (early, male, general dental practitioner)

\section{Awareness of guidelines}

Participants across all career stages reported mixed awareness of social media policies, including GDC, trust and organisational policies:

- '[...] as an undergraduate, we had some guidelines I don't know what they were called. I think there are BDJ or GDC guidelines' P8 (early, male, trainee)

- 'Well the GDC have put out some guidelines or rules, I'm not sure what they call them, about behaviour on social media' P13 (middle, male, general dental practitioner).

\section{Naivety and maturity}

Some participants did not express a need for learning development in this area; although they recognised e-professionalism courses as being useful, many didn't see it as a need for themselves. This may have reflected the lack of self-awareness around personal education on the topic because participants saw themselves as not using social media or considered themselves intermittent users, hence it was not a priority for their learning needs.

It was felt that teaching on e-professionalism is needed for those at an undergraduate level, newly qualified dentists or for those beginning to engage with social media, delivered by those who understand the field, approach the challenges without causing anxiety and avoid fearmongering, to support the use of social media platforms:

- 'I'm not sure if many people would be interested in doing it [the course] voluntarily [...] probably good for university students, think as I said as they have less of an idea of professionalism start to preclude, then people who have been in the profession for a while. Or on the flipside, again stereotypically older users who might not be so proficient in social media and apps and things' P8 (early, male, trainee)

- 'I was at dental school [...] they weren't really experienced on social media [...] they were just saying don't do it to scare us to not do it, because that's what they knew about it [...] it would be useful to have [...] someone who knows about it to come out and be like it's a tool it's very useful. But I want to know how to use it rather than just saying don't do it' P2 (early, male, general dental practitioner)

- 'I know that they've employed a professional blogger to lecture the students from the word go' P14 (late, female, consultant).

\section{Emerging spectrum of types of social media users}

When analysing the data, there were clear differences in the ways that participants described their activity and use of social media. A spectrum of eight user types of dentists using social media emerged from the participant responses; this included characteristics of users, social media in learning and what might change their use. The suggested categories have been mapped and full details can be seen in Table 3 . A relationship was exhibited in the way users 
used social media for professional purposes and personal purposes. The spectrum of users suggests that the categories are fluid and notably may be influenced by the users' career stage, job role, environment, social media experience and platforms being used. Users may fit into more than one category as their professional and personal use may differ and change over time.

\section{Discussion}

This is the first known study in the UK to explore the use of social media among dentists in different career stages, delivering services in primary and secondary care settings. The study found that social media use, for general and professional purposes, overlapped and was considered in the context of risks and benefits.

\section{Defining social media}

Participants provided different definitions of 'social media' and the platforms included, although the majority highlighted the same concept, of connecting with people and

\begin{tabular}{|c|c|c|c|c|c|c|c|c|}
\hline Category & $\begin{array}{l}\text { Deleters (former } \\
\text { users) }\end{array}$ & Avoiders & Secondary users & Occasional users & $\begin{array}{l}\text { Followers, } \\
\text { observers }\end{array}$ & Seekers & $\begin{array}{l}\text { Cautious, } \\
\text { limited, } \\
\text { engaged users }\end{array}$ & Active users \\
\hline \multirow{4}{*}{ 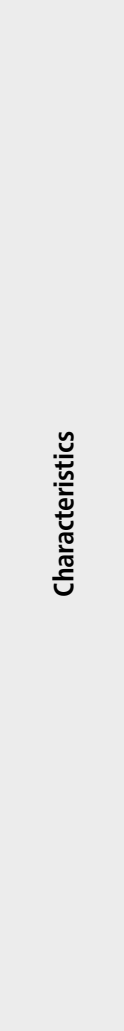 } & $\begin{array}{l}\text { Can't see } \\
\text { benefits }\end{array}$ & $\begin{array}{l}\text { May see } \\
\text { benefits }\end{array}$ & Sees benefits & Sees benefits & Sees benefits & Sees benefits & Sees benefits & Sees benefits \\
\hline & Risks > benefits & $\begin{array}{l}\text { Aware of risks, } \\
\text { risks > benefits }\end{array}$ & Aware of risks & Aware of risks & Aware of risks & Aware of risks & Aware of risks & $\begin{array}{l}\text { Aware of some } \\
\text { risks }\end{array}$ \\
\hline & \multicolumn{2}{|c|}{$\begin{array}{l}\text { Seeks information through real life } \\
\text { Lacks skills to join and will/desire } \\
\text { to join } \\
\text { Unaware of how it works } \\
\text { Doesn't feel the need, not missing } \\
\text { out }\end{array}$} & $\begin{array}{l}\text { Lacks skills to } \\
\text { join and will/ } \\
\text { desire to join }\end{array}$ & $\begin{array}{l}\text { Does not feel } \\
\text { the need to } \\
\text { engage, does } \\
\text { not understand } \\
\text { the purpose of it }\end{array}$ & $\begin{array}{l}\text { Filters } \\
\text { information on } \\
\text { social media } \\
\text { Lacks confidence } \\
\text { to post in forums }\end{array}$ & $\begin{array}{l}\text { Filters } \\
\text { information on } \\
\text { social media }\end{array}$ & $\begin{array}{l}\text { Filters } \\
\text { information on } \\
\text { social media } \\
\text { Contributes } \\
\text { depending on } \\
\text { knowledge of } \\
\text { area } \\
\text { Conscious } \\
\text { of posting } \\
\text { information }\end{array}$ & $\begin{array}{l}\text { Filters } \\
\text { information on } \\
\text { social media } \\
\text { Contributes } \\
\text { where possible }\end{array}$ \\
\hline & $\begin{array}{l}\text { Do it for } \\
\text { self-protection } \\
\text { No longer has } \\
\text { will/need to } \\
\text { utilise social } \\
\text { media } \\
\text { Could be afraid, } \\
\text { had adverse } \\
\text { experience, had } \\
\text { enough }\end{array}$ & $\begin{array}{l}\text { Do it for } \\
\text { self-protection } \\
\text { Do not want } \\
\text { their life on } \\
\text { show, want to } \\
\text { be a gatekeeper } \\
\text { of that } \\
\text { information and } \\
\text { choose who to } \\
\text { share with }\end{array}$ & $\begin{array}{l}\text { Gets things on } \\
\text { social media } \\
\text { signposted to } \\
\text { them } \\
\text { Sign-poster } \\
\text { may/may } \\
\text { not make } \\
\text { comments, } \\
\text { person posts on } \\
\text { user's behalf } \\
\text { Possibly for self- } \\
\text { protection, lack } \\
\text { of need, fear } \\
\text { May get invited } \\
\text { but doesn't join }\end{array}$ & $\begin{array}{l}\text { Not a priority } \\
\text { May require } \\
\text { guidance or } \\
\text { want to use } \\
\text { more }\end{array}$ & $\begin{array}{l}\text { Do it for } \\
\text { self-protection } \\
\text { Does not feel } \\
\text { the need to } \\
\text { Lacks confidence } \\
\text { to post in forums } \\
\text { Privately } \\
\text { messages if } \\
\text { wants to learn } \\
\text { more }\end{array}$ & $\begin{array}{l}\text { Intention to } \\
\text { actively seek } \\
\text { information } \\
\text { Searching } \\
\text { through forums } \\
\text { Privately } \\
\text { messages if } \\
\text { wants to learn } \\
\text { more } \\
\text { May post in } \\
\text { forums if have } \\
\text { confidence } \\
\text { May look } \\
\text { through social } \\
\text { media but not } \\
\text { join }\end{array}$ & $\begin{array}{l}\text { May or may not } \\
\text { have necessary } \\
\text { skills for } \\
\text { self-protection } \\
\text { Feels confident } \\
\text { to be able to } \\
\text { engage and post } \\
\text { Conscious of } \\
\text { impact of users } \\
\text { around them, } \\
\text { deliberates } \\
\text { May use closed } \\
\text { rather than open } \\
\text { platforms }\end{array}$ & $\begin{array}{l}\text { May or may not } \\
\text { have necessary } \\
\text { skills for } \\
\text { self-protection } \\
\text { Feels confident } \\
\text { to be able to } \\
\text { engage and post } \\
\text { Impacts on } \\
\text { others around } \\
\text { them }\end{array}$ \\
\hline 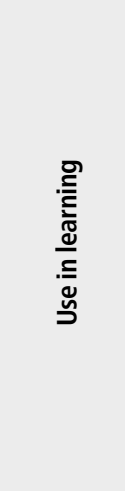 & $\begin{array}{l}\text { Traditional } \\
\text { methods of } \\
\text { learning (eg } \\
\text { face-to-face, } \\
\text { hands-on } \\
\text { courses, } \\
\text { meetings, } \\
\text { journals, } \\
\text { professional } \\
\text { societies) }\end{array}$ & $\begin{array}{l}\text { Traditional } \\
\text { methods of } \\
\text { learning (eg } \\
\text { face-to-face, } \\
\text { hands-on } \\
\text { courses, } \\
\text { meetings, } \\
\text { journals, } \\
\text { professional } \\
\text { societies) }\end{array}$ & $\begin{array}{l}\text { Traditional } \\
\text { methods of } \\
\text { learning (eg } \\
\text { face-to-face, } \\
\text { hands-on } \\
\text { courses, } \\
\text { meetings, } \\
\text { journals, } \\
\text { professional } \\
\text { societies) }\end{array}$ & $\begin{array}{l}\text { Traditional } \\
\text { methods of } \\
\text { learning (eg } \\
\text { face-to-face, } \\
\text { hands-on } \\
\text { courses, } \\
\text { meetings, } \\
\text { journals, } \\
\text { professional } \\
\text { societies) }\end{array}$ & $\begin{array}{l}\text { Uses more } \\
\text { professionally, to } \\
\text { own benefit } \\
\text { Place for online } \\
\text { learning } \\
\text { Traditional } \\
\text { methods of } \\
\text { learning (eg } \\
\text { face-to-face, } \\
\text { hands-on } \\
\text { courses, } \\
\text { meetings, } \\
\text { journals, } \\
\text { professional } \\
\text { societies) }\end{array}$ & $\begin{array}{l}\text { Uses more } \\
\text { professionally, to } \\
\text { own benefit } \\
\text { Place for online } \\
\text { learning } \\
\text { Traditional } \\
\text { methods of } \\
\text { learning (eg } \\
\text { face-to-face, } \\
\text { hands-on } \\
\text { courses, } \\
\text { meetings, } \\
\text { journals, } \\
\text { professional } \\
\text { societies) }\end{array}$ & $\begin{array}{l}\text { Uses more } \\
\text { professionally, to } \\
\text { own benefit } \\
\text { Place for online } \\
\text { learning } \\
\text { Traditional } \\
\text { methods of } \\
\text { learning (eg } \\
\text { face-to-face, } \\
\text { hands-on } \\
\text { courses, } \\
\text { meetings, } \\
\text { journals, } \\
\text { professional } \\
\text { societies) }\end{array}$ & $\begin{array}{l}\text { Uses more } \\
\text { professionally, to } \\
\text { own benefit } \\
\text { Place for online } \\
\text { learning } \\
\text { Traditional } \\
\text { methods of } \\
\text { learning (eg } \\
\text { face-to-face, } \\
\text { hands-on } \\
\text { courses, } \\
\text { meetings, } \\
\text { journals, } \\
\text { professional } \\
\text { societies) }\end{array}$ \\
\hline 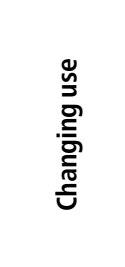 & $\begin{array}{l}\text { Might change } \\
\text { if saw some } \\
\text { benefit } \\
\text { Might join if felt } \\
\text { like missing out } \\
\text { on information } \\
\text { May require } \\
\text { support }\end{array}$ & $\begin{array}{l}\text { Might change } \\
\text { if saw some } \\
\text { benefit } \\
\text { Might join if felt } \\
\text { like missing out } \\
\text { on information } \\
\text { May require } \\
\text { support }\end{array}$ & $\begin{array}{l}\text { Chooses to be } \\
\text { secondary user } \\
\text { dependent on } \\
\text { platform used }\end{array}$ & $\begin{array}{l}\text { If become more } \\
\text { engaged with } \\
\text { platforms, or } \\
\text { feeling of need } \\
\text { increases }\end{array}$ & $\begin{array}{l}\text { When moves up } \\
\text { priority list } \\
\text { Might post if felt } \\
\text { more confident } \\
\text { in an online } \\
\text { environment }\end{array}$ & $\begin{array}{l}\text { Might post if felt } \\
\text { more confident } \\
\text { in an online } \\
\text { environment }\end{array}$ & $\begin{array}{l}\text { Might post if felt } \\
\text { more confident } \\
\text { in an online } \\
\text { environment }\end{array}$ & $\begin{array}{l}\text { May change } \\
\text { activity based } \\
\text { on experience, } \\
\text { or if sees risks } \\
\text { more than } \\
\text { benefits }\end{array}$ \\
\hline
\end{tabular}

Suggested user types are not mutually exclusive, and users may fit between different categories and will be constantly changing. These factors can be influenced by age, employment setting, job role, experiences of social media and the notion that different platforms are used with different intent. For example, blogs, Twitter and Linkedln are all seen as professional platforms; Facebook and Instagram can mix between personal and professional 
sharing and exchanging information. As seen in the literature, there is lack of agreement on a definition with the awareness that this technology is changing everyday, which makes it hard to define; ${ }^{5}$ perhaps a more updated definition is needed.

\section{Emergence of user types}

Interestingly, the list of social media user types emerged when asking how platforms are being used in general and in dentistry. Eight user types were identified as a 'continuum' and the way in which platforms were used personally was likely to be reflected in professional use. There has been limited research on the study of typology and social media in healthcare. A study carried out by Brandtzaeg and Heim (2011) proposed a typology of social media network site users among the Norwegian population. Drawing on theoretical models, five user types were identified: sporadics, lurkers, socialisers, debaters and actives. ${ }^{41}$ Our research findings supported the presence of a range of similar categories, while also including additional categories and labels such as deleters, avoiders and secondary users. This may be related to the fact that we were studying a sample of dentists in London by career stage and setting, all of which warrant additional investigation. Within our study, the findings suggested that participants were not confined to one category and will be constantly changing and overlapping between user types, dependent on the platform being used. This study provides initial findings; however, further research is needed in this area.

\section{Risks and benefits}

The risks and benefits identified in this study support the published literature in this area. ${ }^{9,15,22,42,43}$ From the data, it emerged that participants reported a range of management techniques such as filtering information on platforms, considering sources or placing boundaries, and trying to strike a balance when using social media in a way perceived to be safe and effective. The participants also highlighted that social media plays an important role in personal professional development, allowing knowledge and information to be exchanged, making it a convenient and fast way of learning when used effectively. It appears to facilitate a type of learning to exist outside the 'classroom', with 24-hour access enabled by devices such as mobile phones, tablets and laptops. It has the potential to subconsciously influence users to consider certain aspects of dentistry; this risk occurs due to the platform algorithms, creating a 'bubble.' This is potentially explained by the fact that the majority of friendships made at dental school are professional colleagues. Social media provides the opportunity for users to see what others in the workforce are doing and highlight courses and opportunities which they may not have come across, as they largely work in professional isolation in primary care.

\section{Use of social media}

Participants working in secondary care reported the advantages of social media as a tool for those based in primary care who may otherwise be feeling isolated, as it allows communication, connectivity and provides a platform for discussion. It appears to replicate or replace experiences where dentists are more likely to be around colleagues and can carry out these activities face to face. Those in their early career stages noted how social media has been able to support networking opportunities in dentistry. One female participant reported that social media and online learning allowed her to keep in touch with the profession while on maternity leave. These aspects could be explored through further research. Other areas for exploration include the age-related hierarchy of social media usage. For example, older people are more likely to use Facebook whereas younger people are more likely to use Instagram. As social media develops - and new platforms are developed, such as TikTok - this may pose future challenges to younger generations entering the dental professional. Guidance of social media usage in the profession will need to be reviewed on an ongoing basis to reflect societal changes, and will need to be regularly updated through professional organisations and regulators.

\section{Guidance on e-professionalism}

Lastly, when exploring the participants' understanding of e-professionalism and social media usage, the lack of structure and need for further training to ensure social media is being used in a professional manner was highlighted. All participants highlighted the need for integration within the undergraduate curriculum, which supports existing research. ${ }^{19,34,44}$ Increasingly, students will need to be equipped with the knowledge and skills to safely access social media sites in their professional capacity. Having university educators who understand this topic area and approach education on social media without a parental approach or causing fear is important for learning. It was also highlighted that courses could be beneficial for all career stages, especially for those who are considering to start using social media, and it could be useful to refresh those who have been using it for a long time, particularly when fitness to practice cases are on the rise in social media. ${ }^{34}$ Considering current context within the COVID-19 pandemic, it is possible that more challenges with using social media among professionals may arise.

\section{Strengths and limitations}

Limitations of this study exist and must be acknowledged. Firstly, the sample size and locality of the study was purposely limited. Research was carried out within the geographical constraints of London with a small purposive sample of dentists. While small and London-based, however, the sample participants covered a range of characteristics and rich data were gathered in this previously unexplored area. The use of social media could differ by region and it is recommended that this research is replicated across the UK to build a fuller picture of social media use that can inform professional policy and action, and explore how we can best keep abreast of changes over time and their potential risks. Some participants in the study mentioned that their use of social media may have been different had they not been based in the capital city; for example, they may have turned to social media more often to identify job opportunities. Replication of this study will also provide opportunity for further corroboration of study findings in regard to the spectrum of user types which emerged.

Secondly, as participants were purposively sampled across the profession, there was lack of engagement with dentists during the recruitment stage; many individuals lacked time or interest in the topics and so chose not to participate, GDPs in their late career stage being the most challenging to recruit. This could have been due to not perceiving themselves as social media users, therefore considering themselves irrelevant to the study. GDPs' perspectives and actions are important to understand; they form the majority of the profession and their working environments are very different to those in hospital, community and university settings where there may be more face-to-face engagement with other dentists. This study also only focused on dentists; other dental care professionals were not included. A UK-wide study would enable differences between different branches and roles of the profession to be explored further, allowing testing and refinement of user types.

Thirdly, as a health professional, a statement mentioning the GDC was made during the 
consent-taking process, which was a stark reminder for dentists of professional conduct. The research team and some participants acknowledged that this could have skewed responses in the interviews. During the past year when the study was carried out, social media has become much more relevant and litigious. ${ }^{34}$ This was recognised as a challenge in dentists conducting research among dentists, as professional standards need to be maintained, thus negative experiences may be underreported in this study. Participants recognised the tension between professional and personal life, and the challenges this can entail in keeping the two separate. It is also possible that underreporting may have existed, and the use of other social media platforms such as dating apps were not explored in this study as they were beyond the scope of this research.

\section{Summary}

The findings of this study suggest a list of social media user types among London-based dentists across different career stages and working in different settings. There was variation in their pattern of use, ranging from active users to avoiders, with some actively deleting their social media profiles. There also appears to be a relationship between user type and how social media is used in a personal and professional manner. Participants used social media as a way of creating networks, seeking advice, support and information from colleagues. This offers an opportunity to support dentists through potentially isolated professional careers in primary care. Social media may play a varied, and changing, role in information sharing and CPD for those who use it. There is some evidence that it may also play a role among those at an earlier stage in their career, through exposure to different aspects of dentistry. Lastly, the findings on professionalism in social media warrant future consideration and research, particularly with regards to integrating social media into the educational curriculum for undergraduates and postgraduates, as well as CPD to equip dentists with the adequate skills in this area.

Social media is an integral part of society and can be an important tool that can greatly benefit the profession if it is utilised and managed in a professional manner. The pace of change of social media is such that there will be significant change over the course of a dentist's professional career. It will be important for all members of the profession to stay up to date, and to manage the risks and engage the benefits of these platforms.

\section{Acknowledgements}

The authors would like to thank the participants for their time in taking part in the study.

\section{Conflict of interest}

The authors declare no conflicts of interest.

\section{References}

1. World Wide Web Foundation. History of the Web. 2018 Available at https://webfoundation.org/about/vision/ history-of-the-web/ (accessed November 2020).

2. Office for National Statistics. Internet access households and individuals. 2018. Available at https:// www.ons.gov.uk/peoplepopulationandcommunity/ householdcharacteristics/

homeinternetandsocialmediausage/bulletins/ internetaccesshouseholdsandindividuals/2019 (accessed November 2020)

3. Carr C TH, Rebecca A H. Social Media: Defining, Developing and Divining. At/ J Commun 2015; 23: 46-65.

4. Obar J A, Wildman S. Social media definition and the governance challenge: An introduction to the special issue. Telecomm Policy 2015; 39: 745-750.

5. Kaplan A M, Haenlein M. Users of the world, unite! The challenges and opportunities of social media. Bus Horiz 2010; 53: 59-68.

6. Bhola S, Hellyer P. The risks and benefits of social media in dental foundation training. Br Dent J 2016; 221: 609-613.

7. Melkers J, Hicks D, Rosenblum S, Isett K I, Elliott J. Dental Blogs, Podcasts, and Associated Social Media: Descriptive Mapping and Analysis. J Med Internet Res 2017: DOI: 10.2196/jmir.7868.

8. Petrucci A M, Chang M, Wexner S D. Social Media: Changing the Paradigm for Surgical Education. Clin Colon Rectal Surg 2017: 30: 244-251.

9. Spallek H, Turner S P, Donate-Bartfield E et al. Social Media in the Dental School Environment, Part A: Benefits, Challenges, and Recommendations for Use. J Dent Educ 2015; 79: 1140-1152.

10. Ventola C L. Social media and health care professionals: benefits, risks, and best practices. P T 2014; 39: 491-520.

11. General Dental Council. Guidance on using social media. 2016. Available at https://www.gdc-uk.org/docs/defaultsource/student-faqs/guidance-on-using-social-media. pdf (accessed November 2020)

12. General Dental Council. CPD for dental professionals. 2019. Available online at https://www.gdc-uk.org/ education-cpd/cpd (accessed February 2018).

13. General Dental Council. Enhanced CPD scheme 2018 2018. Available online at https://www.gdc-uk.org/ education-cpd/cpd/enhanced-cpd-scheme-2018/ (accessed February 2018).

14. Bullock A, Firmstone V, Fielding A, Frame J, Thomas $D$, Belfield C. Participation of UK dentists in continuing professional development. Br Dent J 2003; 194: 47-51.

15. Spallek H, Turner S P, Donate-Bartfield E et al. Social Media in the Dental School Environment, Part B: Curricular Considerations. J Dent Educ 2015; 79: 1153-1166.

16. Maloney S, Tunnecliff J, Morgan P et al. Translating Evidence Into Practice via Social Media: A MixedMethods Study. J Med Internet Res 2015; DOI: 10.2196/ jmir.4763.

17. Trathen A, Gallagher J E. Dental professionalism: definitions and debate. BrDent J 2009; 206: 249-253.

18. Neville P, Waylen A. Social media and dentistry: some reflections on e-professionalism. Br Dent J 2015; 218: 475-478.

19. Holden A. Social media and professionalism: does the profession need to re-think the parameters of professionalism within social media? Aust Dent J 2017; 62: 23-29

20. Kenny P, Johnson I G. Social media use, attitudes, behaviours and perceptions of online professionalism among dental students. Br Dent J 2016; 221: 651-655.

21. Hamm M P, Chisholm A, Shulhan J et al. Social media use by health care professionals and trainees: a scoping review. Acad Med 2013; 88: 1376-1383.
22. Cheston C C, Flickinger T E, Chisolm M S. Social media use in medical education: a systematic review. Acad Med 2013: 88: 893-901.

23. Snelson C L. Qualitative and Mixed Methods Social Media Research: A Review of the Literature. Int J Qual Methods 2016: DOI: 10.1177/1609406915624574.

24. Hazzam J, Lahrech A. Health Care Professionals' Social Media Behaviour and the Underlying Factors of Social Media Adoption and Use: Quantitative Study. J Med Internet Res 2018; DOI: 10.2196/12035.

25. Hagg E, Dahinten V S, Currie L M. The emerging use of social media for health-related purposes in low and middle-income countries: A scoping review. Int J Med Inform 2018; 115: 92-105

26. Vanzetta M, Molin A D, Vellone E, Alvaro R, Arrigoni C. Social media and nurse education: an integrative review of the literature. Ann Ig 2016; 28: 187-201.

27. Surani Z, Hirani R, Elias A et al. Social media usage among health care providers. BMC Res Notes 2017: 10: 654.

28. Bolderston A, Watson J, Woznitza N et al. Twitter journal clubs and continuing professional development: An analysis of a \#MedRadJClub tweet chat. Radiography (Lond) 2018; 24: 3-8.

29. Gonzalez S M, Gadbury-Amyot C C. Using Twitter for Teaching and Learning in an Oral and Maxillofacial Radiology Course. J Dent Educ 2016; 80: 149-155.

30. Snyman L, Visser J H. The adoption of social media and social media marketing by dentists in South Africa. SADJ 2014; 69: 258, 260-264.

31. Arnett M R, Loewen J M, Romito L M. Use of social media by dental educators. J Dent Educ 2013; 77: 1402-1412.

32. Haas J, Park J H. Management \& marketing: orthodontic marketing through online social networks. J Clin Orthod 2012; 46: 159-164.

33. Knosel M, Jung K, Bleckmann A. YouTube, dentistry, and dental education. J Dent Educ 2011; 75: 1558-1568.

34. Neville P. Social media and professionalism: a retrospective content analysis of Fitness to Practise cases heard by the GDC concerning social media complaints. $\mathrm{Br}$ Dent J 2017; 223: 353-357.

35. de Peralta T L, Fields Farrior O, Flake N M, Gallagher D, Susin C, Valenza J. The Use of Social Media by Dental Students for Communication and Learning: Two Viewpoints: Viewpoint 1: Social Media Use Can Benefit Dental Students' Communication and Learning and Viewpoint 2: Potential Problems with Social Media Outweigh Their Benefits for Dental Education. J Dent Educ 2019; 83: 663-668.

36. Office for National Statistics. Internet access Households and Individuals. Table 10: Internet Activities by age group, sex and disability status. 2019. Available at https://www.ons gov.uk/peoplepopulationandcommunity/ householdcharacteristics/

homeinternetandsocialmediausage/datasets/ internetaccesshouseholdsandindividualsreferencetables (accessed November 2020).

37. Ritchie J, Lewis J, Nicholls C M, Ormston R (eds) Qualitative research practice: a guide for social science students and researchers. Second edition. Los Angeles: Sage, 2014

38. Creswell J W. Research design: qualitative, quantitative, and mixed methods approaches. Fourth edition. California: Sage, 2014

39. Larkin $M$, Thompson A R. Interpretive phenomenological analysis in mental health and pyschotherapy research. In Harper D, Thompson A R (eds) Qualitative Research Methods in Mental Health and Pyschotherapy: An Introduction for Students and Practitioners. pp 101-116. Chichester: Wiley-Blackwell, 2012

40. Braun V, Clarke V. Using thematic analysis in pyschology. Qual Res Psychol 2006; 3: 77-101.

41. Brandtzaeg P B, Heim J. A typology of social networking site users. Int J Web Based Commun 2011; 7: 28-51.

42. Oakley $\mathrm{M}$, Spallek H. Social media in dental education a call for research and action. J Dent Educ 2012; 76: 279-287.

43. Shuttleworth J, Smith W. NHS dentistry: The social media challenge. Br Dent J 2016; 220: 153.

44. Dobson E, Patel P, Neville P. Perceptions of e-professionalism among dental students: a UK dental school study. Br Dent J 2019; 226: 73-78. 